\title{
Karakteristik Fisikokimia Gelatin Kulit Ikan Sapu-Sapu (Hyposarcus pardalis) Hasil Ekstraksi Asam
}

\author{
Sandra Hermanto*, M. Rafi Hudzaifah, Anna Muawanah \\ Program Studi Kimia, Fakultas Sains dan Teknologi UIN Syarif Hidayatullah Jakarta \\ J1. Ir. H. Juanda No. 95 Ciputat Jakarta 15412 \\ *Email: hermantokimia@uinjkt.ac.id
}

\begin{abstract}
Abstrak
Pemanfaatan kulit ikan sebagai sumber alternatif gelatin menjadi kajian yang cukup menarik terlebih dengan adanya isu dan kekhawatiran mengenai status kehalalan gelatin. Penelitian ini bertujuan untuk mengeksplorasi potensi kulit ikan sapu-sapu (Hyposarcus pardalis) sebagai sumber alternatif gelatin yang dilanjutkan dengan pengujian sifat fisikokimia sebagai parameter standar kualitas gelatin. Proses ekstraksi gelatin dilakukan dengan merendam kulit ikan sapu-sapu dalam asam fosfat $2 \%, 4 \%, 6 \%(\mathrm{v} / \mathrm{v})$ dan asam asetat $2 \%, 4 \%, 6 \%(\mathrm{v} / \mathrm{v})$ dengan perbandingan kulit ikan:asam (1:3) dan lama perendaman 16 jam kemudian dilanjutkan dengan ekstraksi air hangat pada suhu $70^{\circ} \mathrm{C}$ selama 2 jam. Analisis total randemen dan karakteristik struktur molekul gelatin dilakukan pada tahap awal dan dilanjutkan dengan pengujian sifat fisikokimianya meliputi uji proksimat (kadar air, abu, protein lemak dan kadar logam), uji viskositas, uji titik leleh, uji titik gel, uji $\mathrm{pH}$, uji titik isoelektrik dankekuatan gel.Hasil penelitian menunjukkan bahwa perendaman dengan asam fosfat $4 \%$ menghasilkan rendemen terbanyak (11.6\%).Hasil analisis FTIR pada kedua perlakuan menunjukkan spektrum gelatin yang memiliki kemiripan dengan spektrum FTIR gelatin babi. Pengujian sifat fisikokimia menunjukkan gelatin hasil ekstraksi asam fosfat $4 \%$ memiliki $\mathrm{pH} 4.78$, titik isoelektrik 8.37, titik gel $11.5^{\circ} \mathrm{C}$, titik leleh $27{ }^{0} \mathrm{C}$, viskositas $12.7 \mathrm{cP}$, kekuatan gel 416.57 bloom kadar air 7.5\%, kadar abu 9.4\%, kadar lemak 10.3\% dan kadar protein $66.6 \%$. Hasil pengujian kadar logam berat $(\mathrm{Hg} 0.012 \mathrm{mg} / \mathrm{Kg}, \mathrm{Pb} 7.69 \mathrm{mg} / \mathrm{Kg}, \mathrm{Cd} 2.49 \mathrm{mg} / \mathrm{Kg}, \mathrm{Cu}$ $0.99 \mathrm{mg} / \mathrm{Kg}$ dan $\mathrm{Zn} 11.10 \mathrm{mg} / \mathrm{Kg}$ ) menunjukkan kandungan logam berat pada gelatin hasil ekstraksi asam fosfat masih berada dibawah ambang batas kecuali untuk logam $\mathrm{Cd}$ dan $\mathrm{Pb}$ dimana menurut SNI 7387:2009 kadar maksimum Cd 0.1 mg/Kg, Hg 0.5 mg/Kg, Pb 0.3 mg/Kg. Secara keseluruhan sifat fisikokimia gelatin kulit ikan sapu-sapu sudah memenuhi standar mutu gelatin kecuali untuk kadar abu, kadar lemak, viskositas dan kekuatan gel yang nilainya lebih tinggi dari yang dipersyaratkan.
\end{abstract}

Kata kunci: Ekstraksi, gelatin, hidrolisis asam, hyposarcus pardalis

\begin{abstract}
The benefit of fish skin as an alternative source of gelatin has been chalanging today through the issues and regarding to the halal status of gelatin. This study aims to explore the potential use of Sapu-sapu fish skin (Hyposarcus pardalis) as an alternative source of gelatins. Physicochemical properties determinated as a standard quality of gelatin. Fish skin gelatin carried out by pretreated sapu-sapu fish skin in phosporic acid 2\%, 4\%, 6\% (v/v) and acetic acid $2 \%, 4 \%, 6 \%$ (v/v) independently for 16 hours continued by water extraction on $70{ }^{\circ} \mathrm{C}$ for 2 hours. The yield of gelatin and characteristic of molecular structure analyzed by FTIR though analysis of physicochemical properties consist of proximate (moisture, ash , fat and protein assay), viscosity, melting point, gelling point, $\mathrm{pH}$, isoelectric point and gel strength. The results showed that fish skin gelatin extracted in phosphoric acid $4 \%$ had bigest randemen (11.6\%) and close similarly with molecular structure characteristic of porcine skin gelatin as a standard. Phsycochemical properties of fish skin gelatin from phosphoric acid $4 \%$ extracted had $\mathrm{pH} 4.78$, Isoelectric Point 8.37, gelling point $11.5^{\circ} \mathrm{C}$, melting point $27{ }^{\circ} \mathrm{C}$, viscosity $12.7 \mathrm{cP}$, gel strength 416.57 bloom, moisture $7.5 \%$, ash content $9.4 \%, 10.3 \%$ fat and $66.6 \%$ protein content. While the results of heavy metal ( $\mathrm{Hg}$ $0.0012 \mathrm{mg} / \mathrm{Kg}, \mathrm{Pb} 7.69 \mathrm{mg} / \mathrm{Kg}, \mathrm{Cd} 2.49 \mathrm{mg} / \mathrm{kg}, \mathrm{Cu} 0.99 \mathrm{mg} / \mathrm{Kg}, \mathrm{Zn} 11.10 \mathrm{mg} / \mathrm{Kg}$ ) are still bellow the limit allowable in SNI 7387:200 except for $\mathrm{Cd}$ and $\mathrm{Pb}$ with not allowed on processed food fish. Overall physicochemical properties of sapu-sapu fish skin gelatin meet the quality standard of gelatin except for ash and fat content, viscosity and gel stength.
\end{abstract}


Keywords : acid pretreatment, extraction, gelatin, , Hyposarcus pardalis

\section{PENDAHULUAN}

Gelatin merupakan protein larut air yang diperoleh dari hidrolisis parsial kolagen yang banyak digunakan untuk berbagai keperluan industri, baik industri pangan maupun non-pangan karena memiliki sifat yang khas, yaitu dapat berubah secara reversibel dari bentuk sol ke gel, mengembang dalam air dingin, dapat membentuk film, mempengaruhi viskositas suatu bahan, dan dapat melindungi sistem koloid (Sukkwai et al. 2011).

Dalam industri pangan, gelatin digunakan sebagai pembentuk busa (whipping agent), pengikat (binder agent), penstabil (stabilizer), pembentuk gel (gelling agent), perekat (adhesive), peningkat viskositas (viscosity agent), pengemulsi (emulsifier), finning agent,crystal modifier, dan pengental (thickener). Gelatin juga digunakan dalam industri non-pangan seperti industri farmasi, fotografi, kosmetik, dan industri kertas.Gelatin dapat digunakan dalam bahan pembuat kapsul, pengikat tablet dan pastilles, gelatin sponge, surgical powder, suppositories, medical research, plasma expander, dan mikroenkapsulasi dalam bidang farmasi. Gelatin dalam industri fotografi digunakan sebagai pengikat bahan peka cahaya, dan pada industri kosmetik, gelatin digunakan untuk menstabilkan emulsi pada produk-produk shampo, penyegar dan lotion, sabun (terutama yang cair), lipstik, cat kuku, busa cukur, krim pelindung sinar matahari (Hermanianto 2004).

Di Indonesia, kebutuhan gelatin masih didominasi oleh produk luar yang diimpor dari negara-negara penghasil gelatin. Menurut Wahyuni (2009), Indonesia mengimpor lebih dari 6.200 ton gelatin (tahun 2003) atau senilai US\$ 6.962.237 dari berbagai negara (Perancis, Jepang, India, Brazil, Jerman, Cina, Argentina, dan Australia) dengan harga jual rata-rata di pasar dalam negeri mencapai $\mathrm{Rp}$
60.000 hingga Rp 70.000 setiap kilogramnya (LPPOM 2008). Laporan terkini mengindikasikan produksi gelatin dunia mendekati angka 326.000 ton per tahun, dimana gelatin dari kulit babi sebesar $46 \%$, dari sapi sebesar $29.4 \%$, dari tulang sapi sebesar $23.1 \%$ dan dari sumber lain sebesar $1.5 \%$ (Karim 2009).

Tingginya kebutuhan akan gelatin impor jelas sangat memprihatinkan terutama bagi masyarakat Indonesia yang mayoritas muslim, karena sumber gelatin impor sebagian besar masih menggunakan kulit babi dan jika ditinjau dari aspek kehalalannya babi termasuk hewan yang diharamkan untuk dikonsumsi, sedangkan penggunaan sapi sebagai bahan baku gelatin juga menimbulkan kekhawatiran dalam bidang kesehatan karena adanya wabah penyakit yang dibawa oleh ternak seperti kontaminasi Bovine Spongiform Encephalopathy (BSE) dalam gelatin sapi meski telah terdapat pernyataan dari Scientific Steering Committeee of The European Union bahwa resiko tersebut mendekati nol (Cheowet al. 2007).

Untuk mengatasi ketergantungan akan gelatin impor perlu dicari alternatif produksi gelatin dari sumber yang halal misalnya pembuatan gelatin dari kolagen yang berasal dari kulit ikan (Haug et al. 2003). Kulit ikan dapat dimanfaatkan sebagai sumber gelatin alternatif dan telah banyak dilaporkan pada penelitian-penelitian terkini (Gudmundsson 2002; Go'mez-Guille'n et al. 2005). Menurut Surono et al. (1994) tulang dan kulit ikan sangat potensial sebagai sumber gelatin karena mencakup 10\%-20\% dari total berat tubuh ikan. Jaswir (2007), mengatakan bahwa gelatin dari ikan bisa berkualitas setara dengan babi jika pengolahannya tepat dan akurat.

Salah satu kulit ikan yang berpotensi untuk digunakan sebagai sumber gelatin adalah kulit ikan sapu-sapu, karena ikan sapusapu memiliki kelimpahan yang banyak dan 
bukan merupakan ikan konsumsi serta memiliki nilai ekonomis yang masih relatif rendah. Bagi sebagian besar petani, ikan sapusapu dianggap sebagai hama karena merupakan kompetitor ikan budi daya baik dalam habitat maupun makanan juga dapat merusak pemijahan ikan lain disekitarnya. Jika dibandingkan dengan gelatin dari hewan mamalia, gelatin ikan memiliki beberapa perbedaan sifat antara lain titik leleh dan kekuatan gelnya relatif lebih rendah dari gelatin mamalia (Karimetal. 2008), namun demikian gelatin ikan menunjukkan viskositas yang tinggi dari gelatin mamalia (Leuenberger 1991). Atas dasar hal tersebut, pemanfaatan kulit ikan sapu-sapu diharapkan dapat menjadi solusi alternatif untuk memproduksi gelatin dari sumber yang murah dan halal.

Untuk menentukan kualitas gelatin kulit ikan sapu-sapu sesuai dengan standar yang dipersyaratkan, produk gelatin hasil ekstraksi dikarakterisasi sifat fisikokimianya melalui pengujian proksimat (kadar air, kadar abu, kadar protein, dan kadar lemak), serta uji lainnya meliputi uji viskositas, kekuatan gel, derajat keasaman $(\mathrm{pH})$, titik isoelektrik protein, titik leleh, kandungan logam berat $(\mathrm{Pb}$ dan $\mathrm{Hg}$ ), karakteristik gugus fungsi dan uji organoleptik yang hasilnya dibandingkan dengan gelatin komersial. Dari hasil penelitian ini diharapkan dapat memberikan kontribusi dalam penyediaan sumber gelatin halal melalui pemanfaatan kulit ikan sapu-sapu sebagai komoditas yang kurang memiliki nilai ekonomis.

\section{METODE PENELITIAN}

\section{Alat dan bahan}

Isolasi dan karakterisasi gelatin dilakukan di Pusat Laboratorium Terpadu (PLT) Universitas Islam Negeri Syarif Hidayatullah Jakarta. Bahan baku yang digunakan adalah kulit ikan sapu-sapu yang diperoleh dari pasar ikan di daerah Manggarai, Jakarta Selatan. Bahan lain yang digunakan: Gelatin komersil (halal gelatin) dari Shanghai
Al-Amin Biotech Co. Ltd., serbuk porcine gelatin tipe A (No. katalog: G8150) dan bovine gelatin tipe B (No. katalog: G1393) Sigma-Aldrich, aquades, asam fosfat $\left(\mathrm{H}_{3} \mathrm{PO}_{4}\right)$, asam asetat teknis 98\%, untuk ekstraksi gelatin dan $\mathrm{Na}_{2} \mathrm{CO}_{3}, \mathrm{NaOH}, \mathrm{Na}_{2} \mathrm{~S}_{2} \mathrm{O}_{3}, \mathrm{HCl}$, $\mathrm{K}_{2} \mathrm{SO}_{4}, \mathrm{HgO}, \mathrm{H}_{2} \mathrm{SO}_{4}, \mathrm{HClO}_{4}, \mathrm{HNO}_{3}$, air suling, aseton, dan $\mathrm{H}_{3} \mathrm{BO}_{3}$, natrium asetat serta kertas saring whatman 41 untuk karakterisasi produk gelatin.

Peralatan yang digunakan antara lain wadah tahan asam, pisau, gunting, kain saring, panci kaca, kompor, pengaduk, waterbath incubator dan oven untuk ekstraksi gelatin, timbangan digital, $\mathrm{pH}$ meter, gelas ukur, loyang kaca, grinder, termometer, sentrifuse Sorval, grinder, botol film, pipet volumetrik, tabung reaksi, labu Erlenmeyer, tabung Soxhlet, tanur, cawan, desikator, Rheoner RE 3305, Kett Digital Whitenes Powder C-100, Brookfield Syncro-Lectric Viskometer, magnetic stirrer, dan kjeltec system untuk karakterisasi dan uji organol gelatin.

\section{Preparasi Bahan Baku (Martianingsih, 2009)}

Ikan sapu-sapu segar diambil kulitnya dan dibersihkan dari daging, sisik dan lapisan luar yang mengandung lemak yang masih menempel. Kulit kemudian dicuci dengan air mengalir hingga bersih. Kulit bersih dimasukkan dalam wadah dan ditutup rapat, kemudian disimpan dalam freezer $\left(-20^{\circ} \mathrm{C}\right)$ untuk preparasi dan analisis gelatin berikutnya.

\section{Ekstraksi Gelatin (Pelu et al. 1998)}

Kulit yang telah disimpan dalam lemari pendingin dicuci dengan air mengalir.Kulit kemudian direndam dengan air panas $60-70^{\circ} \mathrm{C}$ selama $1-2$ menit.Kulit lalu ditiriskan dan dipotong kecil-kecil kemudian dicuci dengan air mengalir. Kulit ditimbang \pm 30 gram kemudian direndam dalam larutan asam (asetat dan fosfat) dengan perbandingan kulit ikan dan asam $1: 4$. Konsentrasi asam yang digunakan adalah 2, 4 dan 6\% (v/v) 
dengan lama perendaman masing-masing 16 jam.Setelah mengalami swelling (pengembangan) kulit ikan kemudian dicuci hingga $\mathrm{pH}$ netral (5-6).Selanjutnya dilakukan ekstraksi dalam air panas pada suhu $60{ }^{\circ} \mathrm{C} \pm 3$ ${ }^{\circ} \mathrm{C}$ selama 2 jam dengan ratio bobot kulit ikan dan aquades adalah 1 : 3 . Filtrat yang diperoleh dari proses ekstraksi selanjutnya disaring dengan menggunakan kain saring, kemudian dikeringkan menggunakan oven pada suhu $55^{\circ} \mathrm{C}$ selama 48 jam (2 hari).

\section{Total Rendemen (AOAC 1995)}

Rendemen diperoleh dari perbandingan antara berat serbuk kering gelatin yang dihasilkan dengan berat bahan segar (kulit yang telah dicuci bersih). Besarnya rendemen dapat diperoleh dengan rumus :

Rendemen $(\%)=\frac{\text { total berat gelatin kering }}{\text { berat bahan kulit segar }} \times 100 \%$

\section{Analisis FTIR (Martianingsih 2009)}

Analisis FTIR digunakan untuk mengetahui gugus fungsi-gugus fungsi khas dari gelatin yang telah dipreparasi. Sampel gelatin yang digunakan ialah serbuk gelatin yang diperoleh melalui variasi proses perendaman dalam larutan asam fosfat dan asetat $2 \%, 4 \%$ dan $6 \%(\mathrm{v} / \mathrm{v}) .2 \mathrm{mg}$ sampel dicampurkan dalam $100 \mathrm{mg}$ serbuk kalium bromida $(\mathrm{KBr})$ dan dihomogenkan kemudian dibuat cakram $\mathrm{KBr}$. Selanjutnya sampel discan dalam alat FTIR pada range 4000-500 $\mathrm{cm}^{-1}$ dengan resolusi $4 \mathrm{~cm}^{-1}$.Serapan IR yang dihasilkan dibandingkan dengan gelatin komersil.

\section{Karakterisasi Sifat Fisikokimia Gelatin}

Karakterisasi gelatin kulit ikan sapusapu meliputi uji fisikokimia yaitu viskositas, kekuatan gel, derajat keasaman $(\mathrm{pH})$, titik isoelektrik protein, titik leleh, kandungan logam berat $(\mathrm{Pb}$ dan $\mathrm{Hg})$ dan karakteristif gugus fungsi yang dianalisis dengan FTIR dan dibandingkan hasilnya dengan gelatin komersial. Analisis proksimat dilakukan pada perlakuan terbaik dari masing-masing konsentrasi asam asetat dan asam fosfat.Hasil terbaik dari penelitian ini dilanjutkan dengan pengujian organoleptik yang meliputi warna, tekstur penampakan, dan nilai keseluruhan yang dibandingkan dengan gelatin komersial.

\section{Uji viskositas gelatin (AOAC 1995)}

Larutan gelatin dengan konsentrasi $6.67 \%(\mathrm{~b} / \mathrm{b})$ disiapkan dengan aquades $(7 \mathrm{gr}$ gelatin ditambah $105 \mathrm{ml}$ aquades) kemudian larutan diukur viskositasnya dengan menggunakan alat Brookfield Syncro-Lectric Viscometer. Pengukuran dilakukan pada suhu $60{ }^{\circ} \mathrm{C}$ dengan laju geser $60 \mathrm{rpm}$ menggunakan spindel.Hasil pengukuran dikalikan dengan faktor konversi. Pengujian ini menggunakan spindle no.1 dengan faktor konversinya adalah 1 , nilai viskositas dinyatakan dalam satuan centipoise $(\mathrm{cP})$.

\section{Kekuatan Gel (Stevens et al. 1995)}

Kekuatan gel dilakukan secara objektif dengan menggunakan alat Rheoner RE 3305. Tingkat kekuatan gel dinyatakan dengan satuan bloom yang berarti besarnya gaya tekan untuk memecah deformasi produk. Sebelum digunakan alat disetting agar sesuai dengan jenis produk yang akan diukur gelnya karena standar setting untuk setiap produk berbeda, jarak yang digunakan adalah $400 \mathrm{x}$ $0.01 \mathrm{~mm}$, kecepatan $0.5 \mathrm{~mm} / \mathrm{s}$, sensitifitas 0.2 $\mathrm{v}$ dan silinder probe $5 \mathrm{~mm}$. Cara kerja alat ini yaitu silinder probe $5 \mathrm{~mm}$ tidak bergerak, meja tempat untuk meletakkan contoh yang bergerak ke atas mendekati jarum penusuk, tekanan dilakukan sebanyak satu kali. Hasil pengukuran akan tercetak dalam kertas berbentuk histogram.

\section{Derajat Keasaman $(p H)$ (AOAC 1986)}

Serbuk gelatin sebanyak 0.2 gr didispersi dalam $20 \mathrm{ml}$ aquades pada suhu 80 ${ }^{\circ} \mathrm{C}$.Contoh dihomogenkan dengan magnetic stirer.Kemudian diukur derajat keasamannya $(\mathrm{pH})$ pada suhu kamar dengan $\mathrm{pH}$ meter. 


\section{Titik Leleh (AOAC 1986)}

Larutan gelatin dengan konsentrasi $6.67 \%(\mathrm{~b} / \mathrm{b})$ disiapkan dengan aquades. Contoh diinkubasi pada suhu $10{ }^{\circ} \mathrm{C}$ selama 17 \pm 2 jam. Pengukuran titik leleh dilakukan dengan cara memanaskan gel gelatin dalam waterbath. Diatas gel gelatin tersebut diletakkan gotri dan ketika gotri jatuh ke dasar gel gelatin maka suhu tersebut merupakan suhu titik leleh.

\section{Titik Isoelektrik Protein (AOAC 1986)}

Sebanyak 0.2 gr contoh ditambah dengan $40 \mathrm{ml}$ aquades sebagai pelarut dengan kisaran $\mathrm{pH}$ 4.5-10.5 (interval 0.5). Pengaturan $\mathrm{pH}$ dilakukan dengan menambah $\mathrm{NaOH} 0,5 \mathrm{~N}$ untuk menaikkan $\mathrm{pH}$ dan $\mathrm{HCl} 0.5 \mathrm{~N}$ untuk manurunkan $\mathrm{pH}$. Setelah kondisi tercapai dilanjutkan dengan pengadukan selama 30 menit untuk menyempurnakan reaksi. Larutan yang dihasilkan dipisahkan dengan bagian yang tidak larut dengan cara disentrifuse, kemudian disaring dengan menggunakan kertas saring whatman 41. Filtrat dianalisis kadar nitrogennya dengan metode mikrokjeldahl. Kadar nitrogen terlarut yang paling rendahditentukan sebagai daerah isoelektrik (pl).

\section{Analisis Proksimat}

Analisis proksimat meliputi uji kadar air, kadar abu, kadar protein kadar lemak dan kandungan logam berat. Semua parameter pengujian mengacu pada standar AOAC, (1995) untuk prosedur pengujian gelatin kecuali untuk pengujian kadar logam berat.

\section{Kandungan Logam Berat (Martianingsih,} 2009)

Serbuk gelatin sebanyak 2 gr dimasukkan ke dalam teflon beker dan ditambahkan $1.5 \mathrm{ml} \mathrm{HClO} 4$ dan $3.5 \mathrm{ml} \mathrm{HNO}_{3}$, kemudian teflon beker ditutup dan biarkan selama 24 jam. Selanjutnya teflon beker dan contoh dipanaskan di atas penangas air dengan suhu $60-70{ }^{\circ} \mathrm{C}$ selama $\pm 2-3$ jam (sampai larutan jernih) (bila contoh tidak semua larut, ditambahkan lagi $\mathrm{HClO}_{4}$ dan $3.5 \mathrm{ml} \mathrm{HNO} 3$ ). Kemudian ditambahkan ke dalamnya sebanyak $3 \mathrm{ml}$ air suling bebas ion dan dipanaskan kembali hingga larutan hampir kering, selanjutnya didinginkan pada suhu ruang.Kemudian ditambahkan $1 \mathrm{ml} \mathrm{HNO}_{3}$ pekat dan diaduk pelan-pelan.Selanjutnya ditambahkan $9 \mathrm{ml}$ air suling bebas ion, dan dilakukan pengukuran menggunakan atomic absorption spectrophotometri menggunakan nyala udara esitelin.

\section{HASIL DAN PEMBAHASAN}

\section{Hasil Ekstraksi Gelatin Kulit Ikan Sapu- Sapu}

Ekstraksi gelatin dari kulit ikan sapusapu dilakukan dengan menggunakan larutan asam fosfat dan asam asetat dengan konsentrasi masing-masing 2\%, 4\%, 6\% (v/v) dengan lama perendaman 16 jam. Hasil ekstraksi masing-masing perlakuan diperoleh total randemen sebagaimana terlihat pada tabel 1.

Pada perendaman dengan asam fosfat terlihat kecendrungan nilai rendemen semakin meningkat seiring dengan tingginya konsentrasi demikian juga yang terjadi pada perendaman dengan asam asetat. Kecendrungan naiknya rendemen dengan meningkatnya konsentrasi asam dimungkinkan karena banyaknya ion $\mathrm{H}^{+}$yang berinteraksi dengan struktur tropokolagen.

Tabel 1. Total rendemen gelatin ikan sapu-sapu (Hyposarcus pardalis)

\begin{tabular}{ccccc}
\hline No & Konsentrasi (\%) & Waktu (Jam) & \multicolumn{2}{c}{ Rendemen (\%) } \\
& & & Asam Asetat & Asam Fosfat \\
\hline 1 & 2 & 16 & 1.37 & 4.53 \\
2 & 4 & 16 & 1.6 & 11.6 \\
3 & 6 & 16 & 2.46 & 11.4 \\
\hline
\end{tabular}


Struktur kolagen yang berbentuk tripel heliks akan kehilangan struktur tripel heliksnya karena ikatan hidrogen didalam kolagen dan ikatan antara tropokolagen melemah, sehingga kolagen terkonversi dan menjadi bentuk yang ideal untuk diekstraksi (Martianingsihetal. 2009).

Reaksi pemutusan ikatan kovalen pada struktur tropokolagen akan lebih mudah dilakukan dalam suasana asam dan dengan kekuatan ionik yang lebih besar. Namun demikian konsentasi asam yang terlalu besar akan menghasilkan strukur gelatin dengan massa molekul relatif yang lebih rendah dan viskositasnya semakin berkurang. Penggunaan kedua jenis larutan asam dilakukan untuk menghasilkan gelatin dengan kualitas yang baik. Selain itu juga penggunaan asam fosfat dan asam asetat dikarenakan keduanya merupakan asam lemah sehingga diharapkan tidak akan mendenaturasi secara total kolagen yang akan dikonversi menjadi gelatin.

Ekstraksi dengan air hangat akan meneruskan pemutusan ikatan-ikatan silang, serta untuk merusak ikatan hidrogen yang menjadi faktor penstabil struktur kolagen. Ikatan-ikatan hidrogen yang dirusak dan ikatan-ikatan kovalen yang dipecah akan mendestabilkan tripel helik melalui transisi helik ke gulungan dan menghasilkan konversi yang larut air (Gambar 1).

\section{Karakteristik Struktur Molekul Gelatin}

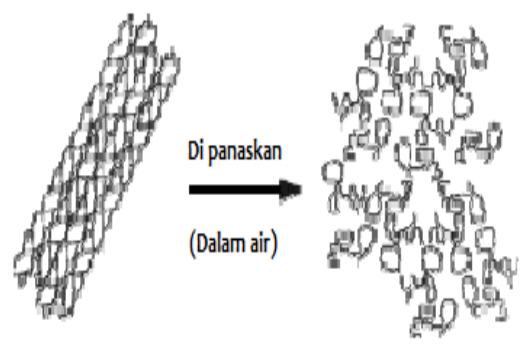

Gambar 1 Proses perusakan struktur kolagen dengan ekstraksi asam(Go'mezGuille'n et al. 2005)

Karakteristik struktur molekul merupakan salah satu penciri penentu keberhasilan proses isolasi gelatin. Analisis yang digunakan untuk mengetahui karakteristik struktur molekul gelatin adalah dengan analisis FTIR untuk mengetahui apakah gelatin hasil ekstraksi memiliki kemiripan dengan struktur gelatin komersial (pembanding). Gelatin seperti umumnya merupakan protein yang terdiri dari senyawa karbon, hidrogen, gugus hiroksil $(\mathrm{OH})$, gugus karbonil $(\mathrm{C}=\mathrm{O})$, dan gugus amina $(\mathrm{NH})$.

Berdasarkan karakteristik gugus fungsinya, serapan khas gelatin dibagi menjadi 4 bagian, yaitu daerah serapan amida A pada bilangan gelombang $3600-2300 \mathrm{~cm}^{-1}$, amida I pada bilangan gelombang 1636-1661 $\mathrm{cm}^{-1}$, amida II pada bilangan gelombang 1560$1335 \mathrm{~cm}^{-1}$, dan amida III pada bilangan gelombang 1300-1200 $\mathrm{cm}^{-1}$ (Muyongga et al. 2004.

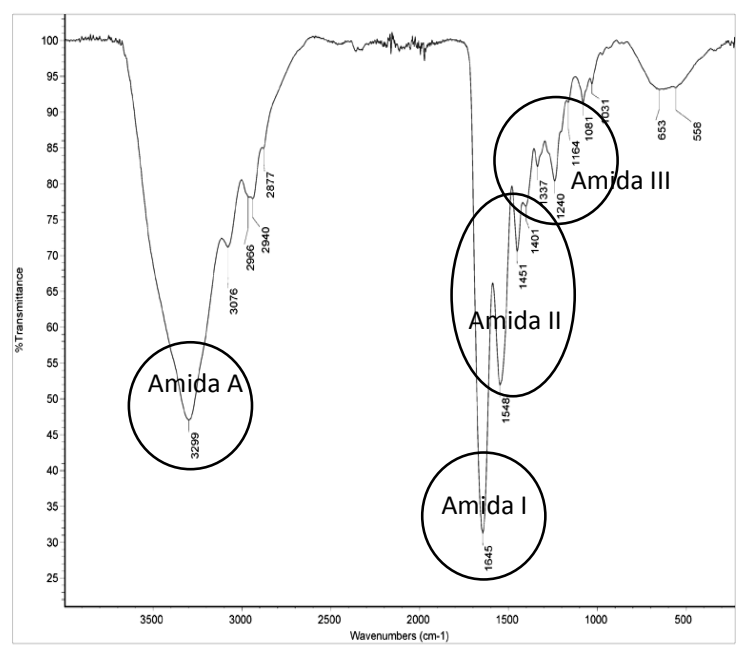

Gambar 2 Profil spektrum FTIR gelatin ikan (Institute of Chemistry, University of Tartu, Estonia)

Hasil analisis FTIR pada semua perlakuan menunjukkan pola serapan khas gelatin yang relatif sama walaupun dengan intensitas yang berbeda yaitu serapan amida A, amida I, amida II dan amida III, seperti yang terdapat pada tabel 2 dan tabel 3 . 
Tabel 2 Puncak serapan FTIR gelatin hasil perendaman asam fosfat

\begin{tabular}{ccccc}
\hline $\begin{array}{c}\text { Asam } \\
\text { Fosfat } \\
(\mathrm{v} / \mathrm{v})\end{array}$ & $\begin{array}{c}\text { Amida A } \\
\left(3600-2300 \mathrm{~cm}^{-1}\right)\end{array}$ & $\begin{array}{c}\text { Amida I } \\
\left(1636-1661 \mathrm{~cm}^{-1}\right)\end{array}$ & $\begin{array}{c}\text { Amida II } \\
\left(1560-1335 \mathrm{~cm}^{-1}\right)\end{array}$ & $\begin{array}{c}\text { Amida III } \\
\left(1300-1200 \mathrm{~cm}^{-1}\right)\end{array}$ \\
\hline $2 \%$ & 3319.69 dan & 1648.30 & $1540.80,1450 \mathrm{dan}$ & 1244.25 \\
& 2939.01 & & 1335.06 & 1242.12 \\
$4 \%$ & $3306.78 \mathrm{dan}$ & 1645.56 & $1539.17,1452.14$ & 1242.51 \\
& 2960.26 & & dan 1334.33 & \\
$6 \%$ & $3302.72 \mathrm{dan}$ & 1647.28 & $1539.74,1452.17$ & 1244.12 \\
Gelatin & 2939.89 & 1649.76 & $1543.88,1453.48$ & \\
Babi & 3303.27 dan & dan 1333.75 & \\
\hline
\end{tabular}

Tabel 3 Puncak serapan FTIR gelatin hasil perendaman asam asetat

\begin{tabular}{|c|c|c|c|c|}
\hline $\begin{array}{l}\text { Asam } \\
\text { Asetat } \\
(\mathrm{v} / \mathrm{v})\end{array}$ & $\begin{array}{c}\text { Amida A } \\
\left(3600-2300 \mathrm{~cm}^{-1}\right)\end{array}$ & $\begin{array}{c}\text { Amida I } \\
\left(1636-1661 \mathrm{~cm}^{-1}\right)\end{array}$ & $\begin{array}{c}\text { Amida II } \\
\left(1560-1335 \mathrm{~cm}^{-1}\right)\end{array}$ & $\begin{array}{c}\text { Amida III } \\
\left(1300-1200 \mathrm{~cm}^{-1}\right)\end{array}$ \\
\hline $2 \%$ & 3318.09 & 1654.08 & $\begin{array}{c}1548.13,1454.64 \\
\text { dan } 1336.52\end{array}$ & 1244.26 \\
\hline $4 \%$ & $\begin{array}{c}3307.37 \text { dan } \\
2961.94\end{array}$ & 1654.27 & $\begin{array}{c}1544.91,1451.38 \\
\text { dan } 1335.63\end{array}$ & 1244.18 \\
\hline $6 \%$ & $\begin{array}{c}3303.03 \text { dan } \\
2958.67\end{array}$ & 1648.30 & $\begin{array}{l}1540.80,1450 \\
\text { dan } v 1335.06\end{array}$ & 1244.25 \\
\hline $\begin{array}{l}\text { Gelatin } \\
\text { Babi }\end{array}$ & $\begin{array}{c}3303.27 \text { dan } \\
2960.89\end{array}$ & 1649.76 & $\begin{array}{c}1543.88,1453.48 \\
\text { dan } 1333.75\end{array}$ & 1244.12 \\
\hline
\end{tabular}

Berdasarkan hasil analisis FTIR (Gambar 3) karakteristik struktur molekul gelatin hasil perendaman asam fosfat $4 \%$ memiliki kemiripan struktur dengan gelatin babi (komersial). Namun demikian diantara keduanya terlihat bahwa intensitas peak pada

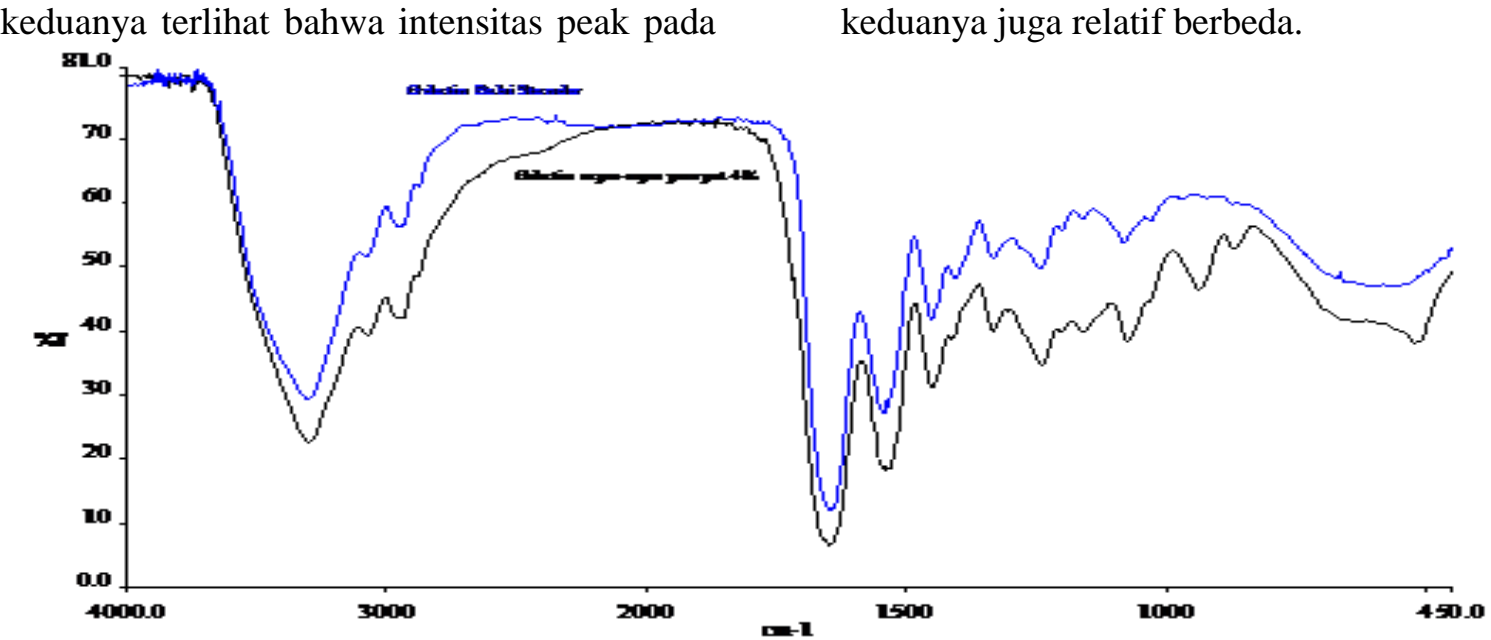

masing-masing bilangan gelombang yang spesifik relatif berbeda. Hal ini kemungkinan juga mempengaruhi sifat fisikokimia diantara keduanya seperti nilai viskositas dan kekuatan gelnya dimana proporsi kolagen dan gelatin gelnya dimana proporsi kolage

Gambar 3 Kemiripan spektrum FTIR gelatin babi dengan gelatin kulit ikan sapu-sapu hasil perendaman asam fosfat $4 \%$ 


\section{Sifat Fisikokimia Gelatin}

Pengujian sifat fisikokimia gelatin dilakukan pada sampel gelatin hasil ekstraksi dengan jumlah randemen terbesar yaitu gelatin hasil ekstraksi asam hosfat 4\%.Hasil pengujian sifat fsisikokimia pada sampel adalah seperti terlihat pada tabel 4 .

Tabel 4 Sifat Fisikokimia gelatin

\begin{tabular}{lcc}
\hline \multicolumn{1}{c}{ Parameter } & Nilai & $\begin{array}{c}* \text { Standar yang } \\
\text { disyaratkan }\end{array}$ \\
\hline Kadar Air (\%) & 7.5 & Maks. 15 \\
Kadar Abu (\%) & 9.4 & $0.3-2$ \\
Kadar Protein (\%) & 66.6 & $>90$ \\
Kadar Lemak (\%) & 10.3 & $<5$ \\
Viskositas (cP) & 12.7 & $15-75$ \\
Kekuatan & 416.7 & $50-300$ \\
Gel(Bloom) & & $3.8-5.5$ \\
pH & 4.78 & $<35$ \\
Titik Leleh $\left({ }^{\circ} \mathrm{C}\right)$ & 27 & $7-9$ (Tipe A) \\
Titik Isoelektrik & 8.37 & \\
\hline *) (GMIA 2012) & &
\end{tabular}

Berdasarkan tabel 4 , terlihat sebagian besar paramater fisikokimia gelatin sudah memenuhi standar yang dipersyaratkan seperti kadar air, pH, titik leleh dan titik isoelektrik. Rendahnya kadar air gelatin kulit ikan sapusapu ini disebabkan oleh proses perendaman asam yang relatf singkat yaitu selama 16 jam, dimana jumlah air yang diserap sangat sedikit dan kehilangan air selama proses pengeringan gelatin yang dihasilkan dari kulit ikan sapusapu hasil ekstraksi asam fosfat $4 \%$ terbentuk setelah dikeringkan pada suhu $55^{\circ} \mathrm{C}$ selama 48 jam.

Nilai pH gelatin merupakan salah satu parameter penting dalam standar mutu gelatin. Pengukuran nilai $\mathrm{pH}$ larutan gelatin penting dilakukan karena $\mathrm{pH}$ larutan gelatin mempengaruhi sifat-sifat yang lainya seperti viskositas dan kekuatan gel (Astawanet al.2002). Menurut GMIA (2012) pH gelatin tipe A berkisar antara $\mathrm{pH}$ 3.8-5.5. Hasil pengukuran nilai $\mathrm{pH}$ gelatin kulit ikan sapu- sapu hasil isolasi asam fosfat $4 \%$ memiliki $\mathrm{pH}$ asam yaitu 4.78 yang masih berada dalam rentang $\mathrm{pH}$ gelatin tipe $\mathrm{A}$.

Rendahnya nilai $\mathrm{pH}$ gelatin kulit ikan sapu-sapu hasil ekstraksi asam fosfat $4 \%$ diakibatkan oleh tingginya konsentrasi asam fosfat yang digunakan.Hal ini diduga karena masih ada sisa-sisa asam fosfat yang digunakan pada saat perendaman yang terbawa pada saat ekstraksi, sehingga mempengaruhi tingkat keasaman $(\mathrm{pH})$ gelatin yang dihasilkan.Namun demikian gelatin dengan $\mathrm{pH}$ rendah mempunyai keuntungan yaitu tahan terhadap kontaminasi mikroorganisme (Hajarwati 2005).

Namun demikian untuk parameter lainnya seperti kadar abu, kadar lemak, viskositas dan kekuatan gel nilainya belum sesuai dengan yang dipersyaratkan. Hasil Pengukuran kadar abu gelatin kulit ikan sapusapu adalah 9.4\%. Hasil ini lebih tinggi dibandingkan kadar abu maksimun yang diatur dalam SNI06-3735-1995 yaitu di bawah $3.25 \%$. Abu adalah zat mineral organik yang tidak ikut terbakar dalam proses pembakaran zat organik .Mineral tersebut diantaranya adalah natrium, klor, kalsium, fosfor, magnesium, belerang dan logam berat (Winarno 1997). Nilai kadar abu suatu bahan pangan menunjukkan besarnya jumlah mineral yang terkandung dalam suatu bahan pangan tersebut. Tingginya kadar abu gelatin kulit ikan kemungkinan disebabkan oleh keberadaan logam-logam berat seperti $\mathrm{Cd}, \mathrm{Pb}$, $\mathrm{Cu}$ dan $\mathrm{Zn}$ dan logam lainnya seperti $\mathrm{Mg}$ dan $\mathrm{Ca}$ yang merupakan mineral yang banyak ditemukan dalam daging ikan yang memiliki titik didih di atas $550{ }^{\circ} \mathrm{C}$.

Kadar lemak menjadi salah satu parameter penting penentu kualitas gelatin.Penentuan kadar lemak perlu dilakukan karena lemak berpengaruh terhadap perubahan mutu gelatin selama penyimpanan. Kerusakan lemak yang utama diakibatkan oleh proses oksidasi sehingga timbul bau dan rasa tengik yang disebut dengan proses ketengikan. Lemak berhubungan dengan mutu karena kerusakan lemak dapat menurunkan 
nilai gizi serta menyebabkan penyimpangan rasa dan bau (Winarno 1997).Gelatin yang bermutu tinggi diharapkan memiliki kandungan lemak yang rendah bahkan diharapkan tidak mengandung lemak (de Man 1997).

Hasil pengukuran kadar lemak gelatin kulit ikan sapu-sapu hasil ekstraksi asam fosfat $4 \%$ relatif cukup besar yaitu $10.3 \%$. Besarnya kadar lemak ini bertolak belakang dengan standar yang dipersyaratkan GMIA (2012), dimana kadar lemak gelatin sebaiknya tidak melebihi $5 \%$ dari total berat gelatin. Tingginya kadar lemak kemungkinan karena factor perlakuan (treatment) selama proses pembuatan gelatin baik pada tahap pembersihan kulit (degreasing) hingga pada tahap penyaringan filtrat hasil ekstraksi yangbelum cukup optimal. Tingginya kadar lemak yang dihasilkan juga mengindikasikan bahwa perlu ada perlakuan khusus yang dilakukan untuk menghilangkan lemak pada kulit ikan sapu-sapu yang dikenal sangat keras misalnya dengan melakukan pretretmen dengan peredaman dalam larutan basa dengan suhu dan waktu yang optimum pada tahap preparasi awal.

Paramater lainnya yang juga pentng dan menjadi standar penentu kualitas gelatin adalah nilai viskositas dan kekuatan gel. Kekuatan gel sangat penting dalam penentuan perlakuan yang terbaik dalam proses ekstraksi gelatin. Pembentukan gel (gelatinisasi) merupakan suatu fenomena penggabungan atau pengikatan silang rantai-rantai polimer membentuk jalinan tiga dimensi yang kontinyu, sehingga dapat menangkap air di dalamnya menjadi suatu struktur yang kompak dan kaku yang tahan terhadap aliran di bawah tekanan.Kemampuan inilah yang menyebabkan gelatin sangat luas penggunaannya, baik dalam bidang pangan, farmasi, dan biadang-bidang lainnya.

Mekanisme yang tepat tentang pembentukan gel dari sol gelatin masih belum diketahui. Molekul-molekul secara individu bergabung dalam lebih dari satu bentuk kristalin membentuk jalinan tiga dimensi yang menjerat cairan dan berikatan silang secara kuat sehingga menyebabkan terbentuknya gel (Gudmundsson 2002). Pendinginan mengakibatkan transisi struktur gulungan yang acak menjadi struktur helik yang baru dan akan memperkuat kekuatan gel gelatin yang dihasilkan. Struktur helik yang baru terbentuk tersebut tidak sama dengan struktur asli kolagen, karena terbatasnya jumlah tripel helik yang terbentuk kembali. Pembentukkan kembali tripel helik mengakibatkan adanya junction zones. Junction zones terjadi pada gelatin dalam bentuk sol ke gel yang dapat dilihat pada gambar 4 .

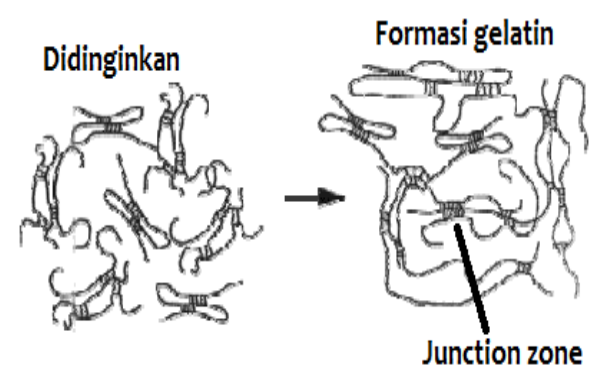

Gambar 4 Junction zones pada molekul gelatin(Martianingsih 2009)

Hasil pengukuran kekuatan gel pada serbuk gelatin kulit ikan sapu-sapu hasil perlakuan ekstraksi asam fosfat $4 \%$ adalah 416.57 bloom, nilai ini lebih tinggi dari yang dipersyaratkan dalam GMIA (2012) untuk gelatin tipe A yaitu 50-300 bloom. Tingginya nilai kekuatan gel ini menunjukkan bahwa proses perendaman dengan asam fosfat $4 \%$ belum cukup optimum dalam mengkonversi struktur tropokolagen yang berbentuk tripel heliks menjadi struktur gelatin yang memiliki struktur alfa heliks. Hal tersebut juga diperkuat dengan hasil analisis FTIR dimana profil spektrum gelatin gelatin ikan sapu-sapu hasil ekstraksi masih mengandung struktur tropokolagen pada daerah amida III.

Di sisi lain, nilai viskositas gelatin ikan sapu-sapu yang diperoleh $12.7 \mathrm{mPa} . \mathrm{s}$ atau sama dengan 12.7 cP.Nilai tersebut melebihi standar yang dipersyaratkan menurut Britis Standard (1975) yaitu 1.5-7 cP. Namun 
apabila mengacu pada GMIA (2012), gelatin kulit ikan sapu-sapu memiliki nilai viskositas di bawah standar yaitu $15 \mathrm{cP}$. Perbedaan nilai viskositas bisa disebabkan oleh karena proses ekstraksi dan komposisi bahan baku yang digunakan dimana masing-masing bahan memiliki tingkat kekuatan ikatan silang tropokolagen yang berbeda-beda selain juga faktor usia, genetik dan faktor lingkungan. Lemahnya ikatan silang menyebabkan kolagen mudah terhidrolisis, hidrolisis ini dapat menurunkan berat molekul gelatin yang pada akhirnya akan menurunkan viskositas larutan gelatin (Choi etal.2000).Viskositas merupakan sifat fisik gelatin yang penting setelah kekuatan gel, karena viskositas mempengaruhi sifat fisik lainnya seperti titik leleh, titik gel, dan stabilitas emulsi.Viskositas gelatin yang tinggi menghasilkan laju pelelehan dan pembentukan gel yang lebih tinggi dibandingkan gelatin yang viskositasnya rendah, dan untuk stabilitas emulsi gelatin diperlukan viskositas yang tinggi (Choietal. 2000).

Hasil pengujian kadar logam berat gelatin kulit ikan sapu-sapu ditampilkan pada tabel 5.

Tabel 5 Kandungan logam berat pada gelatin kulit ikan sapu-sapu hasil perendaman asam fosfat $4 \%$

\begin{tabular}{lcc}
\hline Jenis Logam & $\begin{array}{c}\text { Gelatin Kulit } \\
\text { Ikan Sapu- } \\
\text { Sapu }\end{array}$ & $\begin{array}{c}\text { Total } \\
\text { logam berat *) }\end{array}$ \\
\hline Raksa $(\mathrm{Hg})$ & $0.012 \mathrm{mg} / \mathrm{Kg}$ & Maks. $50 \mathrm{mg} / \mathrm{Kg}$ \\
Timbal $(\mathrm{Pb})$ & $7.69 \mathrm{mg} / \mathrm{Kg}$ & Maks. $50 \mathrm{mg} / \mathrm{Kg}$ \\
Kadmium $(\mathrm{Cd})$ & $2.49 \mathrm{mg} / \mathrm{Kg}$ & Maks. $50 \mathrm{mg} / \mathrm{Kg}$ \\
Tembaga $(\mathrm{Cu})$ & $0.99 \mathrm{mg} / \mathrm{Kg}$ & Maks. $30 \mathrm{mg} / \mathrm{Kg}$ \\
Seng $(\mathrm{Zn})$ & $11.10 \mathrm{mg} / \mathrm{Kg}$ & Maks. $100 \mathrm{mg} / \mathrm{Kg}$ \\
& & \\
\hline *SNI (06-3735-1995) & &
\end{tabular}

Berdasarkan tabel 5terlihat bahwa kadar logam berat gelatin kulit ikan sapu-sapu memiliki nilai yang masih relatif rendah apabila dibandingkan dengan SNI 06-37351995. Namun demikian jika mengacu pada SNI 7387:2009 untuk pangan hasil olahan ikan, kadar $\mathrm{Pb}$ dan $\mathrm{Cd}$ pada gelatin sudah melewati ambang batas dimana kadar logam berat yang diperbolehkan adalah $\mathrm{Cd} 0,1$ $\mathrm{mg} / \mathrm{Kg}, \quad \mathrm{Hg} \quad 0,5 \quad \mathrm{mg} / \mathrm{Kg}, \quad \mathrm{Pb} \quad 0,3 \quad \mathrm{mg} / \mathrm{Kg}$. Mengacu pada standar tersebut sebaiknya untuk pengolahan kulit ikan sapu-sapu menjadi gelatin, sumber atau tempat ikan sapu-sapu hidup perlu diperhatikan. Selain itu perlu juga dilakukan treatment untuk menghilangkan kandungan logam berat tersebut misalnya melalui perendaman dalam larutan basa karena sebagian besar logam akan terendapkan dalam larutan basa. Namun terlepas dari kadar logam berat yang tinggi pada ikan sapu-sapu, ikan sapu-sapu juga mengandung mineral yang penting seperti $\mathrm{Zn}$ dan $\mathrm{Cu}$.

\section{SIMPULAN}

Ekstraksi gelatin dari kulit ikan sapusapu dengan perendaman dalam asam fosfat 4\% selama 16 jam menghasilkan total rendemen terbesar yaitu $11.6 \%(\mathrm{w} / \mathrm{w})$ dengan karakteristik struktur molekul yang relatif mirip dengan spektrum FTIR gelatin babi (komersial).

Sifat fisikokimia gelatin kulit ikan sapu-sapu hasil perendaman asam fosfat $4 \%$ sudah memenuhi standar yang dipersyaratkan dalam SNI No.06-3735-1995dan GMIA (2012) kecuali untuk kadar abu, kadar lemak, viskositas dan kekuatan gelnya yang relatif lebih tinggi dari nilai yang dipersyaratkan.

\section{Saran}

1. Untuk meningkatkan standar kualitas gelatin dari kulit ikan sapu-sapu perlu dilakukan penelitian lebih lanjut dengan mengoptimasi waktu dan suhu perendaman serta perlakuan awal yang sedikit berbeda (misalnya melalui perendaman dalam larutan basa/NaOH) untuk menghilangkan logam berat dan menghasilkan struktur gelatin sesuai dengan standar mutu yang dipersyaratkan.

2. Perlu dilakukan karakterisasi lebih lanjut misalnya melalui analisis bobot molekul gelatin dengan SDS-PAGE dan uji indeks emulsi untuk memperoleh informasi yang lebih lengkap mengenai karakteristik gelatin yang dihasilkan. 


\section{Daftar Pustaka}

[AOAC].1995. Official Methods of Analysis of The Association of Analytical Chemist. Washington.

Apriyantono, H. A, (2003): Makalah Halal: Kaitan Antara Syar'i, Teknologi, dan Sertifikasi, www.indohalal.com/doc-halal2.html

Baker RC, Hahn PW, Robbins KR. 1994. Fundamentals of New Food Product Development. New York (US): Ersevier Science B.V.

[BSN].SNI. 063735. 1995. 1995.Mutu dan Cara Uji Gelatin. Jakarta (ID): Dewan Standarisasi Mutu Pangan.

Charley H. 1982. Encyclopedia of food science and technology.Vol 2. New York (US): John Wiley and Sons.

Cheow CS, NorizahMS, KyawZY,Howell NK. 2007. Preparation and characterisation of gelatins from the skins of sin croaker (Johnius dussumieri) and shortfin scad (Decapterus macrosoma). Food Chemistry. 101(1): 386-391.

Choi SS, Regenstein JM. 2000. Physicochemical and sensory characteristic of fish gelatin. $J$. Food Sci. 65(2): 194-199.

de Man JM. 1997.Kimia Makanan. Terjemahan. K. Padmawinata. Bandung(ID): Penerbit ITB.

Fahrul.2005. Kajian Ekstraksi Gelatin dari Kulit Ikan Tuna (Thunnus alalunga) dan Karakteristiknya Sebagai Bahan Baku Industri Farmasi.Bogor (ID): IPB.

FriessW,Lee G. 1996. Basic thermoanalytical studies of insoluble collagen matrices.Biomaterials.17 (23) : 2289-2294.

[GMAP] Gelatin Manufacture Association of Asia Pacific.2005.About Gelatin. [Internet]. Jakarta(ID): [diunduh pada 2011 September $01]$. Tersedia padahttp://www.gmapgelatin.com/about_gel atin.html.

[GMIA]Gelatin Manufacturers Institute of America.2012.Gelatin Handbook.New York (US): GMIAInc.

Geltech. 2002. What is Gelatin.Jakarta (ID): [diunduh pada 2012 Oktober 18]. Tersedia pada: http://www.Geltech.co.za/gltn1.html.

Go'mez-Guille’n MC, Gime'nez P, Montero.2005. Extraction of gelatin from fish skins by high pressure treatment.Journal of Food Hydrocolloids. 19: 923-928.
Grossman S, BergmanM. 1991.Process for the Production of Gelatin from Fish Skins.European Paten Application 0436266 A1.

Gudmundsson M. 2002.Rheological properties of gelatin.Journal of Food Science. 67(6)

GudmundssonM, Hafsteinssen H. 1997. Gelatin from Cod Skin as Affected by Chemical Treatments.Journal of Food Science. 621(47): 37-39.

Hajarwati. 2006. Sifat fisika dan kimia gelatin tulang sapi dengan perendaman asam klorida pada konsentrasi dan lama perendaman yang berbeda. [Tesis]. Bogor (ID): Sekolah Pasca SarjanaInstitut Pertanian Bogor.

Haug IJ, Kurt ID, Olav S. 2004.Physical behaviour of fish gelatin-k-carrageenan mixtures.Journal Carbohydrate Polymers.56:11-19.

Hermanianto J. 2004. Gelatin: Keajaiban dan Kehalalannya. Jakarta (ID): [diunduh pada 2012 Oktober 18]. Tersedia pada: www.modules.php.htm.

Hinterwaldner, R. 1977. Technology of gelatin manufactureIn: Ward AG, Courts A (ed.). The science and Technology of Gelatin.New York (US): Academic Press.

Institute of Chemistry, University of Tartu, Estonia. http://tera.chem.ut.ee/IR spectra/ index.php?option $=$ com content\&view $=$ article $\&$ id $=102 \&$ Itemid $=70$ didownload tanggal 12 Nopember 2013.

Irawan MD.2009.Studi Perbandingan Kualitas Gelatin Dari Limbah Kulit Ikan Tuna (Thunnus spp.), Kulit Ikan Pari (Dasyatis sp.) dan Tulang Ikan Hiu (Carcarias sp.) sebagai Alternatif Penyedia Gelatin Halal. [Skripsi]. Malang (ID): Fakultas Perikanan, Universitas Brawijaya.

Jaswir. I, 2007. Memahami Gelatin.Jakarta (ID): [diunduh pada 2012 Juni 07]. Tersedia pada: www.beritaiptek.com.

Judoamidjojo RM. 1974.Dasar Teknologi dan Kimia Kulit.Bogor (ID): Fakultas Teknologi Hasil Pertanian IPB.

KarimAA, Bhat R. 2008. Fish Gelatin: Properties. Challenges, and Prospects As An Alternative To Mammalian Gelatins. Food hydrocolloids, 23: 563-576; 656.

Karim AA, Bhat R.2009. Review Fish Gelatin: Properties. Challenges.And Prospects As An Alternative To Mammalian 
Gelatins.Trends in Food Science andTechnology.19: 644-656.

Kottelat M, Whitten AJ, Kartikasari SN, Wiroatmadja S. 1993. Ikan Air Tawar Indonesia Bagian Barat dan Sulawesi. Jerman (DE): Periplus Edition.

Lagler KF, Bardach JE, MillerRR, PassinoDRM. 1977. Ichtiology 2nd ed. New York (US): John Wiley and Sons.

LeuenbergerBH. 1991. Investigation of viscosity and gelation properties of different mammalian and fish gelatins. Food Hydrocolloids. 5(4): 353-361.

LPPOM. 2008. Halal menentramkan umat. Jurnal Halal. 72.

Martianingsih N, Atmaja L.2009. Analisis Sifat Kimia, Fisik, Dan Termal Gelatin Dari Ekstraksi Kulit Ikan Pari (Himantura Gerrardi) Melalui Variasi Jenis Larutan Asam.[Skripsi].Surabaya (ID): Jurusan Kimia Fakultas Matematika dan Ilmu Pengetahuan Alam, Institut Teknologi Sepuluh Nopember.

Muyonga JH, Cole CGB, DuoduKG. 2004. Fourier transform infrared (FTIR) spectroscopic study of acid soluble collagen and gelatin from skins and bones of young and adult Nile perch (Lates niloticus).Food Chemistry.86(3): 325-332.

Nurilmala M. 2004. Kajian potensi limbah tulang ikan keras (Teleostei) sebagai sumber gelatin dan analisis karakteristiknya.[Tesis]. Bogor (ID): Sekolah Pasca Sarjana Institut Pertanian Bogor.

Pelu H, Harwanti S, Chasanah E. 1998. Ekstraksi gelatin dari kulit ikan tuna melalui proses asam. Jurnal Penelitian Perikanan Indonesia. 4(2): 66-74.

Prystupa DA, Donald AM. 1996. Infrared study of gelatin conformations in gel and sol states.Polymer Gels and Networks. 4: 87110.

Puspawati NMIN, Simpen, INS Miwada. 2012.Isolasi Gelatin dari Kulit Kaki Ayam
Broiler danKarakterisasi Gugus Fungsinya dengan Spektrofotometri FTIR.Denpasar (ID): Jurusan Kimia, Fakultas MIPA dan Fakultas Peternakan, Universitas Udayana.

Schrieber R, Gareis H. 2007. Gelatin handbook: Theory and industrial practice. Weinheim (AU): Wiley-VCH Verlag $\mathrm{GmbH} \&$ Co.KGaA.

Sopian, I. 2002.Analisis Sifat Fisik, Kimia dan Fungsional Gelatin yang Diekstrak dari Kulit dan Tulang Ikan Pari.[Skripsi].Bogor (ID):Fakultas Teknologi Pertanian IPB.

Stevens, P., Wijaya, I. and Paterson, J. (1995). Modelling of Physical Properties of Gelatin: Gel Strength. Food Australia, 47 (4), 167-172.

SukkwaiS, Kijroongrojana K, Benjakul S. 2011. Extraction of gelatin from bigeye snapper (Priacanthus tayenus)skin for gelatin hydrolysate production.International Food Research Journal.18(3): 1129-1134.

Surono, Djazuli N, Budianto D, Widarto, Ratnawati, Aji US, Suyui AM, Sugiran. 1994.Penerapan Paket Teknologi Pengolahan Gelatin dari Ikan Cucut. Jakarta (ID): Laporan Balai Pengembangan dan Pengendalian Mutu Hasil Perikanan.

Surono, DjazuliN, BudiyantoD, Widarto, Ratnawati, Aji US, Suyuni AM, Sugiran. 1994. Penerapan Paket Teknologi Pengolahan Gelatin dari Ikan Cucut. Jakarta (ID): Laporan BBMHP.

Wahyuni Mita, Peranginangin Rosmawat. 2009. Perbaikan Daya Saing Industri Pengolahan Perikanan Melalui Pemanfaatan Limbah Non Ekonomis Ikan Menjadi Gelatin, (www.ikanmania.wordpress.com).

Winarno FG.1997. Kimia Pangan dan Gizi. Jakarta (ID): PT Gramedia Pustaka Utama.

Yunanto A. 2000. Luas Relung Dan Tumpang Tindih Makanan Dan Habitat Antara Ikan Sapu-Sapu (Hyposarcus pardalis) Dengan Ikan Lainnya Di Situ Cigudeg, Kabupaten Bogor. [Skripsi].Fakultas Perikanan dan Ilmu Kelautan, Institut Pertanian Bogor. 